\title{
MARKET ORIENTATION, COMPETENCE-BASED MARKETING CAPABILITY AND FIRM DEVELOPMENT
}

\author{
DOI: 10.17261/Pressacademia.2017.760 \\ RJBM- V.4-ISS.4-2017(9)-p.540-548
}

Feng-Hsu Liu ${ }^{1}$

${ }^{1}$ Shih Hsin University, Department of Business Administration, Mu-Cha Rd. Taipei City,116, Taiwan. frankliu@mail.shu.edu.tw

\section{To cite this document}

Liu, F. H. (2017). Market orientation, competence-based marketing capability and firm development. Research Journal of Business and Management (RJBM), V.4, Iss.4, p.540-548.

Permemant link to this document: http://doi.org/10.17261/Pressacademia.2017.760

Copyright: Published by PressAcademia and limited licenced re-use rights only.

\begin{abstract}
Purpose- The topic of competence-based marketing has attracted much attention from business scholars, further exploration of competence-based marketing capability is especially important. The main purpose of this study is to address and investigate the relationship between market orientation and original equipment manufacturer (OEM) suppliers' competence-based marketing capability, along with the impact of competence-based marketing capability on product-linked development and relation-linked development.

Methodology- Based on a sample of 119 Taiwan's OEM suppliers, we used Smart PLS 2.0 to perform SEM and to evaluate both the quality of the measurement model and the interrelationships of the constructs.

Findings- Empirical testing of 119 OEM suppliers suggests that a proactive market orientation has a positive influence on the development of competence-based marketing capabilities. Furthermore, the development of competence-based marketing capability leads OEM suppliers to engage in product-linked and relationship-linked development.

Conclusion- The topic of competence marketing has attracted much attention from business scholars; however, no empirical studies have measured companies' capabilities in competence marketing. Therefore, the framework of this study followed linkages developed from the resource-based view (strategic orientation $\rightarrow$ organizational capabilities $\rightarrow$ organizational performance) for the purpose of exploring the antecedents and effects of CBMC.
\end{abstract}

Keywords: OEM supplier, competence-based marketing, market orientation

JEL Codes: M31, L14

\section{INTRODUCTION}

Competition in the environment puts pressure on original equipment manufacturing $\left(\mathrm{OEM}^{1}\right)$ suppliers to upgrade their abilities and to innovate. Buyers are attracted to a supplier that can move quickly to introduce many competence-based services, ${ }^{2}$ especially when competing suppliers provide only one or two. However, it is often difficult for industrial buyers to accept new services from their suppliers (Korhonen \& Kaarela, 2006). According to the competence-based marketing view, it is only when a supplier is able to make its buyer aware of their competence that the potential competences might be applied (Danneels, 2007). That is, suppliers should pay more attention to the development of the actual competence than to the communication of that competence to buyers (Golfetto \& Gibbert, 2006; Zerbini, Golfetto \& Gibbert, 2007). Zerbini et al. (2007) also suggested that buyers might apply the supplier's competence to their processes when they perceive a strong benefit of that competence. Hence, the further exploration of competence-based marketing capability (CBMC), the ability of firms to communicate the value of various competences to their buyers, is especially important for OEM suppliers to enhance their relationships with their buyers.

As OEM suppliers continuously learn and grasp the lessons of their prior experiences and the best practices of both themselves and their buyers, the scope of their competence might expand from manufacturing only to product design and development, global logistics, and after-sale services (Hobday, 1995; Collis, 1996; Zollo \& Winter, 2002; Liu, Liu and Lin, 2008). Accordingly, in this paper, the competence that will be marketed will be referred to as product-linked competence.

\footnotetext{
${ }^{1}$ OEM (original equipment manufacturing): When a manufacturer follows a buyer's specifications and design to assemble all parts into a product and then ships the product to the buyer.

${ }^{2}$ A competence-based service of OEM suppliers is a type of outsourcing in which the supplier takes on a service formerly conducted by the buyer; in other words, the supplier has a specific ability to provide that service.
} 
Such competences are designed to ensure proper functioning of a product and/or to facilitate the buyer's access to that product in an outsourcing relationship (Mathieu, 2001).

The purposes of this study are as follows. First, although extensive scholarly work has been done on the topic of competence marketing (Zerbini et al., 2007; Berghman, Matthyssens \& Vandenbemt, 2006; Moller, 2006; Li, 2011), few empirical studies have measured skills in competence-based marketing. Second, according to resource dependence theory (RDT) suppliers with a relatively weak position in the market and strong dependence on buyers will seek to reduce uncertainty and manage their dependence by restructuring their exchange relationships (Liu, Tsou \& Chen, 2013). In this regard, a competence-based marketing view is employed to posit that CBMC induces buyer's feedback for supplier's product-linked development and buyer's dependence in supplier's relation-linked development. The third goal of this study is to address and investigate the relationship between market orientation and CBMC. The concepts of proactive market orientation and responsive market orientation will be used (Narver, Slater \& MaLachlan,2004) to discuss which market orientation of a supplier improves supplier's capability to market their competence, in turn increasing the chance that their competence will be applied to the buyer's operating processes. Research framework is shown as below (Figure 1).

Figure 1: A proposed model of the linkages among market orientation, competence-based marketing capability and product and relation-linked development

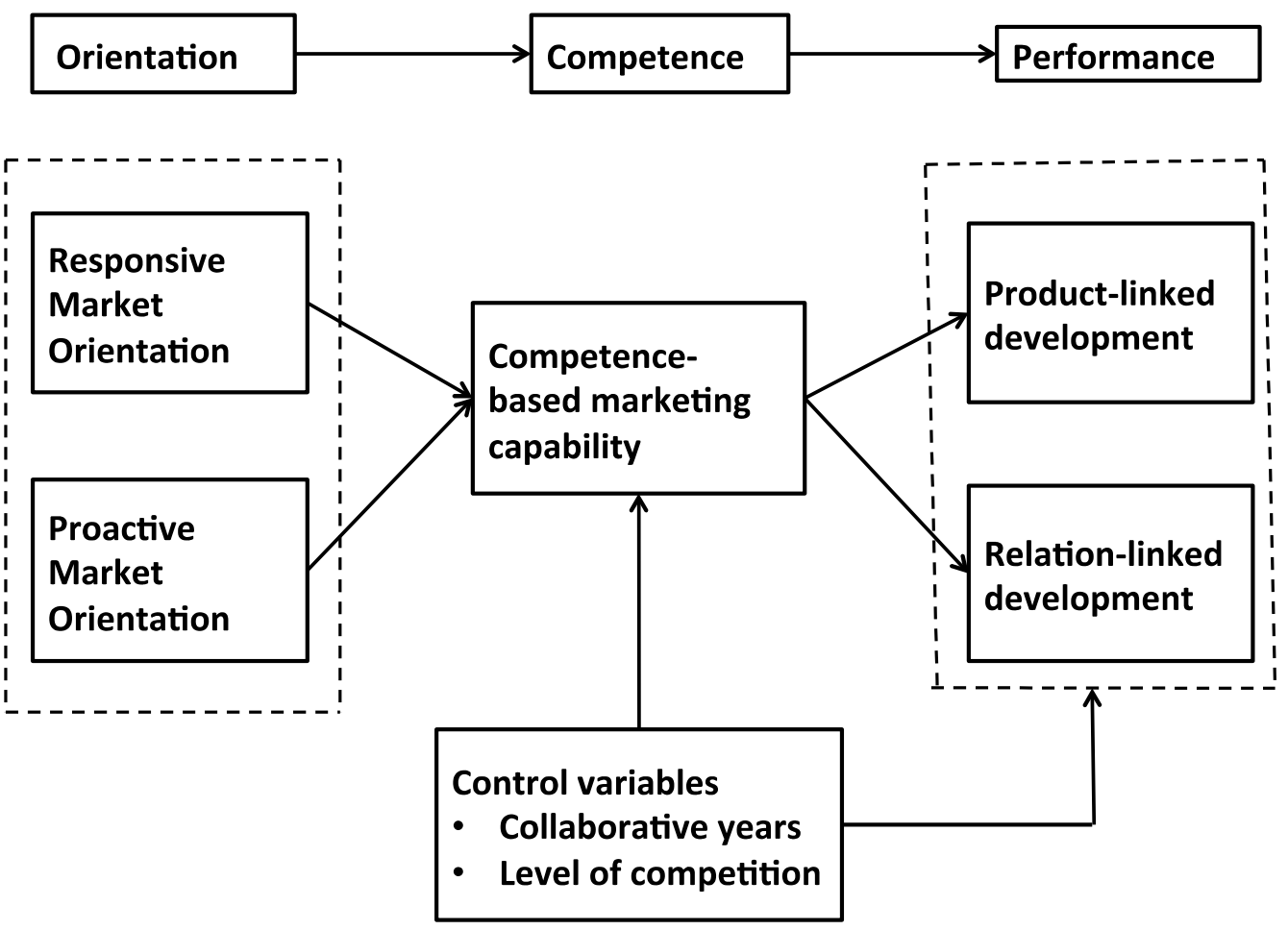

\section{LITERATURE REVIEW AND HYPOTHESIS DEVELOPMENT}

\subsection{Competence-Based Marketing Capability}

Some firms do not know precisely what competences they have. Buyers and suppliers each have their own perceptions of their existing competences, shaped by their mental models and path-dependent successful historical experiences (Markides, 1998). In particular, many manufacturing companies have become more customer-centric and innovative in attempts to differentiate themselves from competitors (Oliva \& Kallenberg, 2003; Grönroos, 2006; Neu \& Brown, 2005; Gebauer, Edvardsson, Gustafsson \& Witell, 2010). To deliver their innovative offerings persuasively and gain a buyer's confidence and trust, marketing competence is needed to protect buyers from misidentifying a supplier's competence (Liu 
\& Liu, 2011). Marketing competence helps buyers to define and clarify the boundaries and attributes of OEM suppliers' competences in a competitive market.

The present study treats $C B M C$ as a composite that requires a formative measure, because $C B M C$ is a higher-order resource that increases in magnitude as each of the three components of competence marketing capability increases. A series of competence-based marketing literature (Zerbini et al., 2007; Berghman, Matthyssens \& Vandenbemt, 2006; Moller, 2006; Danneels, 2007; Li, 2011) led us identify three components of CBMC: communication competence, absorption competence, and joint innovation competence. These components support each other. For example, a higher degree of communication competence enables absorption competence and joint innovation competence, high levels of absorption competence allow internal employees to develop suitable relational skills (i.e., communication competence), and relational skills enable better joint innovation competence.

\subsection{Market Orientation and $\mathrm{CMBC}$}

A market orientation emphasizes commitment to the continuous creation of superior value for customers (Narver and Slater, 1990). Market-oriented firms encourage organization-wide activities to generate and disseminate market intelligence to respond to existing and latent customer needs (Kohli \& Jaworski, 1990; Najafi-Tavani, Sharifi \& Najafi-Tavani, 2016). Hence, the present study proposes that a market orientation plays a decisive role in forming suppliers' CBMC. According to Narver et al. (2004); Tsou, Chen \& Liao (2014), a supplier's market orientation can be divided into two constructs: a proactive market orientation and a responsive market orientation (Narver et al., 2004). A proactive market orientation refers to a firm's endeavors to discover, understand, and satisfy customers' latent needs. In contrast, a responsive market orientation refers to discovering, understanding, and satisfying customers' expressed needs.

\subsection{Responsive Market Orientation and $\mathrm{CMBC}$}

To satisfy buyers' expressed demands, responsive market-oriented suppliers will improve their response time to market as well as reduce total production costs through improved product design and quality and the introduction of new products. It is important to obtain valuable information about the needs of buyers. To provide and acquire specific information, suppliers should have systems in place that identify and record each transaction and interaction with buyers (Chen, Li \& Evans, 2012). Frequent sharing of market information in an organization also provides an environment that drives and encourages internal employees with greater knowledge, skills, and qualifications to provide increasingly integrated solutions for buyers (Li, 2011). Information sharing, both within and between suppliers and buyers, helps suppliers to understand better how they should market their ability to satisfy buyers' needs. Therefore, it is expected that OEM suppliers with a responsive market orientation will increase their degree of familiarity with their buyers and reduce the likelihood of bad communication.

H1: A responsive market orientation has a positive effect on competence-based marketing capability.

\subsection{Proactive Market Orientation and $\mathrm{CMBC}$}

In a competitive environment, it is expected that buyers might commit themselves to establishing, developing, and executing cooperative activities with OEM suppliers (Gulati, 1998) if the potential outcome is desirable (Morgan and Hunt, 1994). A proactive market-oriented supplier would build an innovative environment that encourages employees to improve cross-functional information sharing and coordination. Employees who are satisfied and motivated to create, acquire, and build upon new knowledge will push a firm to satisfy buyers with new services by assimilating current knowledge about buyers, as well as integrating resources and knowledge from all involved departments. Proactive suppliers who can appropriately adapt, integrate, and reconfigure internal and external organizational skills, resources, and functional competences to meet the desires of consumers (Teece et al., 1997) will gain more attention from buyers and therefore have more opportunities to exercise their competences. Liu et al. (2013) also pointed out that many suppliers are devoted to innovation and the development of exclusive business knowledge, helping to sustain a creative advantage in an outsourcing situation. A supplier that is able to present a specific creative skill or good performance will change their buyers' degree of control and encourage communication and trust.

$\mathrm{H} 2$ : A proactive market orientation has a positive effect on competence-based marketing capability.

\subsection{CMBC And Product-linked Development}

Many studies have shown that core competences can lead to rigidity (Leonard-Barton, 1992; Burgelman, 1994), becoming "competence traps" (Levinthal \& March, 1993) that limit the opportunities available to a firm. The buyers in an outsourcing relationship may play an important role in rendering suggestions or providing opportunities to improve suppliers' product development. As OEM suppliers enhance and pay greater attention to communication with their buyers, they might explore the strengths or weaknesses of their competences, giving themselves chances to develop their competences by dynamically 
modifying their abilities to suit the requirements of their buyers in a co-creation process (Hallen, Johanson \& SeyedMohamed, 1991; Newman, Prajogo \& Atherton, 2016).

H3: Competence-based marketing capability has a positive effect on product-linked development.

\subsection{CMBC And Relation-linked Performance}

A supplier with more advantages is more likely to pass on those competitive advantages for their buyers, thus attracting their attention (Pfeffer \& Salancik, 1978). From the buyer's perspective, perceived trust increases with a confident assessment of a partner's present and future resources. Marketing competence is one way that a supplier can show that it can be trusted to respond to a buyer's requirements, in turn enhancing its connection with and engagement in the collaboration between itself and a buyer. Gullen, Johnson \& Sakano (1995) argued that the partners' commitment will develop if the partners perceive value in the benefits derived from the collaboration. Therefore, a competence that is perceived by a buyer can be anticipated to play an important role in inducing that buyer's commitment and may increase its willingness to depend on a supplier. Thus, the final hypothesis is advanced.

H4: Competence-based marketing capability has a positive effect on relation-linked development.

\section{DATA AND METHODOLOGY}

\subsection{Sampling and Data Collection}

In this empirical study, we used a questionnaire to collect data to test the model and hypotheses. The sample frame was drawn from "2013 Top 5,000-the largest corporations Taiwan" published by the Taiwan Credit Information Center 2012. The top 1,000 electronics companies were selected as the sample for this study because the majority of Taiwanese electronics companies are involved in OEM and play an important role in the global electronics market. To increase the quality of the responses to the questionnaire, senior executives of strategic business units were selected as respondents, because they have the greatest and most specific knowledge about their relationships with buyers. Questionnaires, cover letters, and self-addressed stamped return envelopes were mailed to all sample firms on December 22, 2015. Three weeks after the first mailing, reminder letters were sent to the companies that had not yet returned completed questionnaires. After the elimination of incomplete questionnaires, 119 completed copies were returned, for an effective response rate of $11.9 \%$.

A test of non-response was conducted to determine whether any bias was present. All returned questionnaires were categorized as early respondents ( 73 copies) or late respondents ( 46 copies). There was no significant difference among the scale $(p=0.64)$, the length of collaboration $(p=0.69)$, between the two categories, confirming population precision of the sample (Armstrong \& Overton, 1977).

\subsection{Measurement}

Regarding market orientation, this study adopted the Narver et al. (2004) scale to measure proactive market orientation (PMO) and responsive market orientation (RMO). The constructs of PMO and RMO were each measured by three items. PMO reflects the extent to which a firm has attempted to discover, understand, and satisfy the expressed needs of its customers. RMO reflects the extent to which an OEM supplier firm has attempted to discover, understand, and satisfy the latent needs of its customers. CBMC was conceptualized as a higher-order construct that increases in magnitude as each of its three components increases (Diamantopoulos \& Winkelhofer, 2001). Hence, CBMC is a composite that includes three components: communication competence (CC), absorption competence (AC), and joint innovation competence (JIC). We adopted a reflective perspective to measure these three components. We adopted four items based on the work of Joshi (2009) to measure CC. To measure AC, we referred to the research of Tsou and Chen (2012) and employed three questions that measured the ability of firms to assimilate, identify, transform, and make use of new information or knowledge from the environment. We adapted material from Li (2011) to use four items to measure JIC, that is, to reflect the extent to which suppliers engage in developing product-linked innovations, including products and processes, together with the buyer. Items regarding product-linked development with a buyer, reflecting the extent to which a buyer has contributed to suppliers' product design/development, were adapted from Lawson Petersen, Cousins and Handfield (2009). Relation-linked development with the buyer was assessed via adaptations of the scales of Johnston, McCutcheon, Stuart and Kerwood (2004) to obtain four items that measured the suppliers' perceptions of the dependability of buyers.

\subsection{Data Analysis and Results}

To evaluate both the quality of the measurement model and the relationships between the constructs in this structural equation modeling(SEM) model, the partial least squares (PLS) technique (Smart PLS 2.0 software) was employed. In agreement with Tenenhaus, Vinzi, Chatelin, and Lauro (2005) and their suggestion of explaining validation of the PLS model when adopting PLS, an index of goodness of fit (GoF) was used to calculate the geometric mean of the average 
communality and the average $R^{2}$ values $(0<\mathrm{GoF}<1)$. Tenenhaus et al. (2005) suggest that a cut-off value of 0.25 can be considered satisfactory for a medium effect size (Wetzels, Odekerken-Schröder \& van Oppen, 2009). According to the results in Table $3(\mathrm{GoF}=\sqrt{(0.63) \times(0.29)}=0.42)$, the cut-off value of 0.42 exceeds 0.25 .

\subsection{Measurement Model Results}

The PLS method provides details of any significant relationships between survey items and identifies support for the hypotheses. As shown in Table 1, the factor loadings for this research fell between 0.72 and 0.95 , indicating that the designed questions successfully explain the model (Nunnally, 1978). The composite reliability falls in between 0.86 and 0.97 , indicating that the constructs can be considered reliable. Collectively, then, the reliability and internal consistency of the items are acceptable. In addition, this study's average variance extracted values (AVEs) achieves the standard suggested by Fornell and Larcker (1981): at least 0.5 is considered satisfactory and indicates convergent validity. On the other hand, Table 2 shows that the values for average variance extracted from the five constructs in the research are larger than the correlation coefficients, indicating discriminative validity (Fornell and Larcker, 1981). Overall, the results demonstrated the validity of the research constructs.

Table 1: Table for Measurement Properties

\begin{tabular}{|c|c|c|c|c|c|}
\hline & $\begin{array}{l}\text { Construct } \\
\text { identifier }\end{array}$ & Items & Factor loading & $\begin{array}{l}\text { Cronbach } \\
\text { alpha }\end{array}$ & $\begin{array}{l}\text { Composite } \\
\text { reliability }(\rho c)\end{array}$ \\
\hline \multirow{3}{*}{$\begin{array}{l}\text { Responsive market } \\
\text { orientation }\end{array}$} & \multirow{3}{*}{ PMO } & RMO1 & 0.844 & \multirow{3}{*}{0.816} & \multirow{3}{*}{0.894} \\
\hline & & RMO 2 & 0.878 & & \\
\hline & & RMO 3 & 0.856 & & \\
\hline \multirow{3}{*}{$\begin{array}{l}\text { Proactive market } \\
\text { orientation }\end{array}$} & \multirow{3}{*}{ RMO } & PMO 1 & 0.849 & \multirow{3}{*}{0.849} & \multirow{3}{*}{0.902} \\
\hline & & PMO 2 & 0.917 & & \\
\hline & & PMO 3 & 0.846 & & \\
\hline \multirow{4}{*}{$\begin{array}{l}\text { Product-linked } \\
\text { development }\end{array}$} & \multirow{4}{*}{ PLD } & PLD 1 & 0.787 & \multirow{4}{*}{0.795} & \multirow{4}{*}{0.869} \\
\hline & & PLD 2 & 0.780 & & \\
\hline & & PLD 3 & 0.847 & & \\
\hline & & RLD1 & 0.745 & & \\
\hline \multirow{3}{*}{$\begin{array}{l}\text { Relation-linked } \\
\text { development }\end{array}$} & \multirow{3}{*}{ RLD } & RLD 2 & 0.880 & \multirow{3}{*}{0.864} & \multirow{3}{*}{0.917} \\
\hline & & RLD 3 & 0.900 & & \\
\hline & & RLD 4 & 0.881 & & \\
\hline \multirow{3}{*}{$\begin{array}{l}\text { Absorption } \\
\text { competence }\end{array}$} & \multirow{3}{*}{$A C$} & JIC 1 & 0.905 & \multirow{3}{*}{0.875} & \multirow{3}{*}{0.860} \\
\hline & & JIC 2 & 0.952 & & \\
\hline & & $\mathrm{JIC} 3$ & 0.838 & & \\
\hline \multirow{4}{*}{$\begin{array}{l}\text { Joint innovation } \\
\text { competence }\end{array}$} & \multirow{4}{*}{$\mathrm{JIC}$} & $A C 1$ & 0.787 & \multirow{4}{*}{0.810} & \multirow{4}{*}{0.875} \\
\hline & & AC 2 & 0.819 & & \\
\hline & & AC 3 & 0.765 & & \\
\hline & & AC4 & 0.822 & & \\
\hline \multirow{4}{*}{$\begin{array}{l}\text { Communication } \\
\text { competence }\end{array}$} & \multirow{4}{*}{$\mathrm{CC}$} & CC 1 & 0.842 & \multirow{4}{*}{0.803} & \multirow{4}{*}{0.874} \\
\hline & & CC 2 & 0.870 & & \\
\hline & & $\mathrm{CC} 3$ & 0.727 & & \\
\hline & & $\mathrm{CC} 4$ & 0.745 & & \\
\hline
\end{tabular}


Table 2: Mean, SD and Correlations

\begin{tabular}{llllllllllllll}
\hline Construct & & Mean & SD & AVE & $(1)$ & $(2)$ & $(3)$ & $(4)$ & $(5)$ & $(6)$ & (7) & (8) & (9) \\
RMO & $(1)$ & 3.56 & .79 & .73 & .85 & & & & & & & \\
PMO & $(2)$ & 3.76 & .70 & .75 & $.53^{* *}$ & .86 & & & & & & \\
RLD & $(3)$ & 3.93 & .49 & .78 & $.45^{* *}$ & $.38^{* *}$ & .88 & & & & & \\
PLD & $(4)$ & 3.80 & .53 & .62 & $.20^{*}$ & $.38^{* *}$ & $.43^{* *}$ & .78 & & & & \\
AC & $(5)$ & 3.68 & .68 & .80 & $.40^{* *}$ & $.56^{* *}$ & $.42^{* *}$ & $.29^{* *}$ & .89 & & & \\
JIC & $(6)$ & 3.71 & .51 & .63 & $.29^{* *}$ & $.46^{* *}$ & $.42^{* *}$ & $.37^{* *}$ & $.48^{* *}$ & .79 & & \\
CC & $(7)$ & 3.75 & .54 & .63 & $.26^{* *}$ & $.50^{* *}$ & $.50^{* *}$ & $.37^{* *}$ & $.57^{* *}$ & $.65^{* *}$ & .79 & \\
Collaborativ & $(8)$ & & & & - & & & & & & \\
e year & & 3.27 & 1.22 & - & -0.09 & .02 & -0.07 & 0.08 & $.02^{* *}$ & -0.01 & 0.04 & - \\
Competition & $(9)$ & 4.16 & 1.42 & - & -0.03 & -.01 & -.15 & -.01 & -.02 & -.08 & .06 & $.29^{* *}$ & - \\
\hline
\end{tabular}

$* p<.05 .{ }^{* *} p<0.01$. Note: $\mathrm{N}=119$.

1. Figures along the shaded diagonal are values of the square root of the AVE.

Table 3: The results of path analysis

Competence-based marketing capability; $R^{2}=0.39$

Responsive market orientation

Path coefficient (b)

t-value

Proactive market orientation

$\mathrm{H} 1$

0.187

1.828

Competition

$\mathrm{H} 2$

6.347

Collaborative length

Product-linked development; $R^{2}=0.17$

Competence-based marketing capability

Competition

$0.504^{* * *}$

0.211

$-0.016$

0.561

Collaborative length

0.04

4.784

H3

$0.415^{* * *}$

0.047

Relation-linked development $; R^{2}=0.31$

Competence-based marketing capability

0.004

0.005

Competition

0.001

H4 $\begin{array}{ll}0.538^{* * *} & 6.277 \\ -0.128 & 1.653\end{array}$

Collaborative length

$-0.05$

0.554

Average $\mathrm{R}^{2}$

0.29

Average communality

0.63

Goodness-of-Fit

0.42

Notes: Goodness-of-Fit $=\sqrt{[(\text { average communality }) \times(\text { avrage } R \text { square })]} ; * p<.05 .{ }^{* *} p<0.01 .^{* * *} p<0.001$

\subsection{Structural Model}

The construct model of this research was applied to verify the four hypotheses generated from the five constructs. The results of path analysis is shown in Figure 2. In disagreement with $\mathrm{H} 1$, there was not a significant relationship between RMO and $\mathrm{CBMC}(\mathrm{b}=0.187, \mathrm{t}=1.828)$. The results support $\mathrm{H} 2$ in that a significant positive relationship between PMO and CBMC $(b=0.504, t=6.347)$ was seen. The results also support $\mathrm{H} 3$ and $\mathrm{H} 4$ : significant relationships were seen between $\mathrm{CBMC}$ and product-linked development $(b=0.415, t=4.784)$ and between CBMC and relation-linked development $(b=0.538, t=6.277)$. The number of employees and perceived pressure from competition showed no significant relationships with the other variables. 
Figure 2: PLS Results for Direct Effects

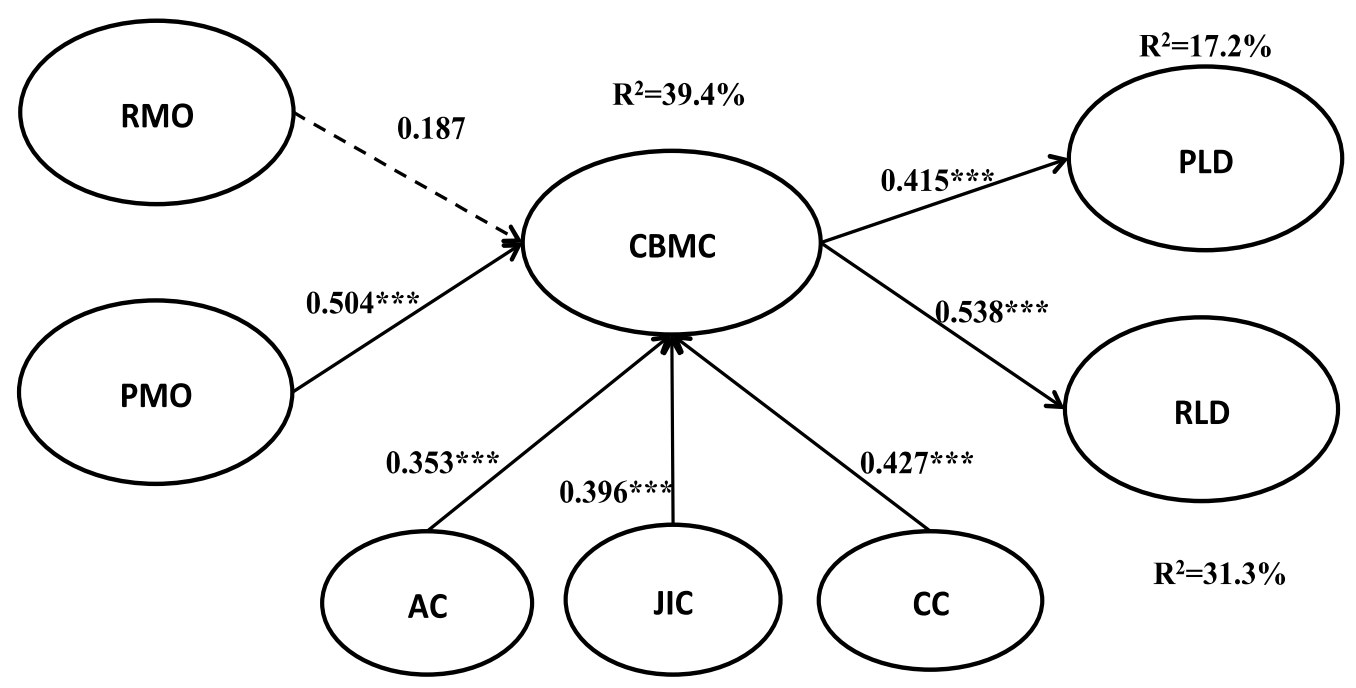

Note. PLS model index: Goodness-of-Fit $=0.42$. RMO, Responsive market orientation ; PMO, Proactive market orientation; CBMC, Competence-based marketing; PLD, Product-linked development; RLD, Relation-linked development; AC, Absorption competence ; JIC, Joint innovation competence; CC, Communication competence. ${ }^{* *} p<0.01,{ }^{* * *} p<0.001$

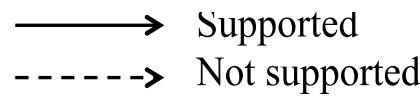

\section{DISSCUSSIONS}

OEM suppliers may have substantial differences in their ability to function within the buyer-supplier relationship. Many manufacturers provide the service of designing and integrating externally supplied products and service components into a customer-specific solution (Salonen, 2011). Although the existence of complex but excellent competence-based service can help to attract buyers, OEM suppliers nevertheless must face and overcome some difficulties that may not be as simple as they appear. The difficulty is that buyers will not form partnerships without a clear understanding of the partner's skills (Prahalad \& Hamel, 1990). Accordingly, sophisticated marketing management that integrates technical knowledge of the competences that buyers seek is needed.

Three competences are suggested for OEM suppliers to build CBMC. The first need is for efficient communication with buyers, which consists of accurate, valuable, and up-to-date information. However, even with this valuable information, without absorption competence, firms will be unable to convert this market information into the required knowledge, nor will they be able to sense market opportunities (Pavlou \& El Sawy, 2004). Second, absorption competence enables suppliers to better apply and adjust their knowledge base in various areas. Finally, in the present study, we argue that OEM suppliers that are able to offer suggestions or opportunities for fostering or reexamining the collaborative relationship will find that joint innovation is an effective way to inform buyers about their activities or competences. Suppliers can gain a buyer's confidence and trust by engaging in joint innovation to resolve a problem resulting from the buyer's competence trap (Ebers \& Grandori, 1997).

In today's rapidly changing environment, firms must develop dynamic capabilities to ensure a continuing competitive advantage in the field of strategic management. Firms must have the ability to repackage their resources and create new capabilities to face a dynamic environment. The result of this research suggests that proactive market-oriented firms pay 
more attention to exploring and generating marketable intelligence and are therefore able to supply decisive and acceptable competences, impressing buyers, who are vulnerable to uncertainties in resource acquisition posed by the changing and competitive environment.

\section{CONCLUSION}

The topic of competence marketing has attracted much attention from business scholars; however, no empirical studies have measured companies' capabilities in competence marketing. Therefore, the framework of this study followed linkages developed from the resource-based view (strategic orientation $\rightarrow$ organizational capabilities $\rightarrow$ organizational performance) for the purpose of exploring the antecedents and effects of CBMC. This study further suggested that a proactive market orientation influences the development of CBMC in OEM suppliers. Furthermore, CBMC leads OEM suppliers to develop superior products and improve relationships with buyers.

\section{REFERENCES}

Armstrong, J. S., \& Overton, T. S. 1977, “Estimating nonresponse bias in mail surveys,” Journal of Marketing Research, Vol. 14 no. 3, pp.396402.

Berghman, L., Matthyssens, P. \& Vandenbempt, K. 2006, "Building competences for new customer value creation: An exploratory study," Industrial Marketing Management, vol. 36 no. 8, pp. 961-973.

Chen, Y. C., Li, P. C. \& Evans, K. R. 2012, "Effects of interaction and entrepreneurial orientation on organizational performance: Insights in market driven and market driving," Industrial Marketing Management, vol. 41, no. 6, pp. 1019-1034.

Collis, D. J. 1996. Organizational capability as a source of profit. In B. Moingeon \& A. Edmondson (Eds.), Organizational learning and competitive advantage (pp. 139-163). London: Sage.

Danneels, E. 2007, “The process of technological competence leveraging," Strategic Management Journal, vol. 28, no.5, pp. 511-533.

Diamantopoulos, A. \& Winkelhofer, H.M. 2001, "Index construction with formative indicators: An alternative to scale development," Journal of Marketing Research, vol.38, no.2, 269- 277.

Ebers, M. \& Grandori, A. 1997, "The forms, costs and development dynamics of inter-organizational networking," In: Ebers, M. (Ed.), The Formation of Inter-Organizational Networks, Oxford University Press, UK, Oxford, pp.3-40

Fornell, C. \& Larcker, D. 1981, "Evaluating structural equation models with unobservable variables and measurement error," Journal of Marketing Research, vol. 18 no. 1, pp. 39-50.

Gebauer, H., Edvardsson, B., Gustafsson, A. \& Witell, L. 2010, "Match or mismatch: Strategy-structure configurations in the service business of manufacturing companies," Journal of Service Research, vol. 13, no. 2, pp.198-215.

Golfetto, F. \& Gibbert, M. 2006, "Marketing competencies and the sources of customer value in business markets," Industrial Marketing Management, vol.35, no.8, pp. 904-912.

Grönroos, C. 2006, “Adopting a service logic for marketing," Marketing Theory, vol. 6, no. 3, pp. 317-333.

Gulati, R. 1998, “Alliances and networks," Strategic Management Journal, vol. 19, pp. 293-317.

Gullen, J.B., Johnson J.L. \& Sakano, T. 1995, "Japanese and local partner commitment to IJVs: Psychological consequences of outcomes and investments in the IJV relationship," Journal of International Business Studies, vol. 26, pp. 91-116.

Hallen, L., Johanson, J. \& Seyed-Mohamed, N. 1991, “Interfirm adaptation in business relationships," Journal of Marketing, vol. 55, no. 2, pp. 29-37.

Hobday, M. 1995, Innovation in East Asia: The challenge to Japan, VT: Edward Elgar, Brookfield.

Joshi, A.W. 2009, “Continuous supplier performance: Effects of collaborative communication and control,” Journal of Marketing, vol. 73, no. 1,pp. 133-150.

Kohli, A. K. \& Jaworski, B. J. 1990, "Market orientation: The construct, research propositions, and managerial implications," Journal of Marketing, vol. 54, no. 2, pp. 1-18.

Korhonen, H. M. E. \& Kaarela, I. 2006, “Corporate customers' resistance to industrial service innovation," International Journal of Innovation Management, vol. 15, no. 3, pp. 479-503

Lawson, B., Petersen, K. J., Cousins, P. D., and Handfield, R. B. 2009, "Knowledge sharing in interorganizational product development teams: the effect of formal and informal socialization mechanisms," Journal of Product Innovation Management, vol.26, no.2, pp. 156-172.

Levinthal, D. A. \& March, J. G. 1993,“The Myopia of Learning,” Strategic Management Journal, vol. 14, pecial Issue, pp.95-112.

Li, L.Y. 2011, "Marketing of competence-based solutions to buyers in exploratory relationships: Perspective of OEM suppliers," Industrial 
Marketing Management, vol. 40 no.7, pp. 1206-1213

Liu, F. H., Liu, H. Y. \& Lin, T. L. 2008, "The competence and constraints of brand-building for contract manufacturers," Journal of Brand Management, vol. 15, no. 6, pp. 412-432.

Liu, F.H., Tsou, H.T. \& Chen, L.J. 2013, "The impact of OEM supplier initiatives on buyer competence development: The moderating roles of collaborative relationship and competitive environment," Asia Pacific Journal of Management, vol. 30, no. 4, pp. 1285-1303

Liu, H. Y. \& Liu, F.H. 2011, "The process of competence leveraging in related diversification: A case of technology management at a composite-material company," Technology Analysis \& Strategic Management, vol. 23, no. 2, pp. 209-227.

Markides, C. 1998, "Strategic innovation in established companies," Sloan Management Review, vol. 39, pp. 31-42.

Mathieu, V. 2001, "Product services: From a service supporting the product to a service supporting the client," Journal of Business \& Industrial Marketing, vol.16, no.1, pp. 39-58.

Moller, K. 2006, "Role of competences in creating customer value: A value-creation logic approach," Industrial Marketing Management, vol. 35, no.8, pp.913-924

Morgan, R. M. \& Hunt, S. D. 1994, “The Commitment-Trust Theory of Relationship Marketing,” Journal of Marketing, vol. 58, no. 3, pp. 2038.

Najafi-Tavani, S, Sharifi, H., \& Najafi-Tavani, Z. 2016, "Market orientation, marketing capability, and new product performance: the moderating role of absorptive capacity," Journal of Business Research, vol. 69, no. 11. pp. 5059-5064.

Narver, J.C. \& Slater, S.F. 1990, "The effect of a market orientation on business performance," Journal of Marketing, vol. 54, no. 4, pp. 2035.

Narver, J.C., Slater, S.F. \& MaLachlan, D.L. 2004, "Responsive and proactive market orientation and new-product success," Journal of Production Innovation Management, vol. 21, no. 5, pp. 334-347.

Neu, W.A. \& Brown, S.W. 2005, "Forming successful business-to-business services in goods dominant firms," Journal of Service Research, vol. 8, no. 1, pp. 3-17.

Newman, A, Prajogo, D., \& Atherton, A. 2016, "The influence of market orientation on innovation strategies," Journal of service theory and practice, vol. 26 , no. 1 , pp. $72-90$.

Nunnally, J. C. 1978, Psychometric theory (2nd Edition), McGraw-Hill, New York.

Oliva, R. \& Kallenberg, R. 2003, “Managing the transformation from products to services," International Journal of Service Industry Management, vol. 14, pp.160-72.

Pavlou, P.A. \& El Sawy, O.A. 2006, "From IT leveraging competence to competitive advantage in turbulent environments: The case of new product development," Information Systems Research, vol. 17 no. 3, pp. 198-227.

Pfeffer, J. \& Salancik, G.R. 1978, The External control of organizations: A resource dependence perspective, New York: Harper \& Row.

Prahalad, C. K., \& Hamel, G. 1990. The core competence of corporation. Harvard Business Review, vol. 68, no. 3, pp. 9-91.

Salonen, A. 2011, "Service transition strategies of industrial manufacturers," Industrial Marketing Management, vol. 40, no.5, pp. 683-690.

Teece, D. J., Pisano, G. \& Shuen, A. 1997, “Dynamic capabilities and strategic management," Strategic Management Journal, vol. 18, no.7, pp. 509-533.

Tenenhaus, M., Vinzi, V.E., Chatelin, Y.M. \& Lauro, C. 2005, "PLS path modeling," Computational Statistics \& Data Analysis, vol. 48, no. 1, pp. 159-205.

Tsou, H. \& Chen, J. 2012, "The influence of interfirm codevelopment competency on e-service innovation," Information \& Management, vol. 49, no 3-4, pp. 177-189.

Tsou. H.T., Chen, J.S., \& Liao W.H. 2014, "Market and technology orientations for service delivery innovation: The link of innovative competence," Journal of Business \& Industrial Marketing, Vol. 29 no. 6, pp. 499-513.

Wetzels, M., Odekerken-Schröder, G. \& van Oppen, C. 2009, “Using PLS path modeling for assessing hierarchical construct models: Guidelines and empirical illustration," MIS Quarterly, vol. 33, no. 1, pp. 177-195.

Zerbini, F., Golfetto, F. \& Gibbert, M. 2007, "Marketing of competence: Exploring the resource-based content of value-for-customers through a case study analysis," Industrial Marketing Management, vol. 36, no. 6, pp. 784-798.

Zollo, M. \& Winter, S. 2002, “Deliberate learning and the evolution of dynamic capabilities,” Organization Science, vol. 13, no. 3, pp. 339351. 